\title{
Lower Thigh Pain
}

National Cancer Institute

\section{Source}

National Cancer Institute. Lower Thigh Pain. NCI Thesaurus. Code C35789.

A painful sensation in the distal thigh area. 